\title{
CONDITION OF LIPID PEROXIDE OXIDATION AND ANTIOXIDANT SYSTEM IN PATIENTS WITH INFECTIOUS MONONUCLEOSIS
}

\author{
Mikola Shustval, Tetiana Liadova ${ }^{2}$, Olha Volobuieva ${ }^{2}$, Ksenia Pavlikova ${ }^{2}$, Alla Gamilovska ${ }^{2}$ \\ ${ }^{1}$ Kharkiv Medical Academy of Postgraduate Education, 58 Amosova St., Kharkiv, 61176, Ukraine, \\ email: office@med.edu.ua \\ ${ }^{2}$ V. N. Karazin Kharkiv National University, 6 Svobody Sq., Kharkiv, 61022, Ukraine, \\ e-mail: med@karazin.ua
}

The indicators of the activity of lipid peroxidation and the antioxidant system were studied in dynamics in 158 patients with infectious mononucleosis depending on the severity of the clinical course of the disease.

It is proved that lipid peroxidation is significantly activated in patients with infectious mononucleosis as the severity of the disease increases and therefore increases the oxidative activity of blood plasma, the concentration of dyne conjugates and malondialdehyde in the blood, decreases the activity of antioxidant enzymes of erythrocytes (catalase, superoxide dismutase, glutathione peroxidase, glutathione reductase), glutathione peroxidase and glutathione reductase activity in plasma and lowering the concentration of total and reduced glutathione in the blood, as well as reduce the antioxidant activity of blood plasma and erythrocytes.

KEY WORDS: infectious mononucleosis, lipid peroxides, antioxidant system, catalase, superoxide dismutase, glutathione peroxidase, glutathione reductase, dyne conjugates, malonic dialdehyde, glutathione

\section{СТАН ПЕРЕКИСНОГО ОКИСЛЕННЯ ЛІПІДІВ ТА АНТИОКСИДАНТНОЇ СИСТЕМИ У ХВОРИХ НА ІНФЕКЦЙНИЙ МОНОНУКЛЕОЗ}

Шустваль М. Ф. ${ }^{1}$, Лядова Т..$^{2}$, Волобуєва О. В. ${ }^{2}$, Павликова К. В. ${ }^{2}$, Гаміловська А. П. ${ }^{2}$

${ }^{1}$ Харківська медична академія післядипломної освіти, вул. Амосова, 58, м. Харків, 61176, Україна

${ }^{2}$ Харківський національний університет імені В. Н. Каразіна, пл. Свободи, 6, м. Харків, 61022,

Україна

У 158 хворих на інфекційний мононуклеоз вивчені в динаміці показники активності перекисного окислення ліпідів і антиоксидантної системи в залежності від тяжкості клінічного перебігу захворювання.

Доведено, що у хворих на інфекційний мононуклеоз протягом наростання тяжкості захворювання достовірно активується перекисне окислення ліпідів, в зв'язку з чим підвищуються окислювальна активність плазми крові, концентрація в крові дієнових кон'югатів і малонового діальдегіду, відбувається ослаблення активності антиоксидантної системи, що асоційоване зі зниженням активності антиокислювальних ферментів еритроцитів (каталази, супероксиддисмутази, глутатіонпероксидази, глутатіонредуктази), активності глутатіонпероксидази і глутатіонредуктази в плазмі крові і зниженням концентрації загального та відновленого глутатіону в крові, а також зниженням антиоксидантної активності плазми крові та еритроцитів.

КЛЮЧОВІ СЛОВА: інфекційний мононуклеоз, перекиси ліпідів, антиоксидантна система, каталаза, супероксиддисмутаза, глутатіонтероксидаза, глутатіонредуктаза, дієнові кон'югати, малоновий діальдегід, глутатіон 


\section{СОСТОЯНИЕ ПЕРЕКИСНОГО ОКИСЛЕНИЯ ЛИПИДОВ И АНТИОКСИДАНТНОЙ СИСТЕМЫ У БОЛЬНЫХ ИНФЕКЦИОННЫМ МОНОНУКЛЕОЗОМ}

Шустваль Н. Ф. ${ }^{1}$, Лядова Т. И. ${ }^{2}$ Волобуева О. В. ${ }^{2}$, Павликова К. В. ${ }^{2}$, Гамиловская А. П. Севастьянова Т. В.

${ }^{1}$ Харьковская медицинская академия последипломного образования, ул. Амосова, 58, г. Харьков, 61176, Украина

${ }^{2}$ Харьковский национальный университет имени В. Н. Каразина, пл. Свободы, 6, г. Харьков, 61022 , Украина

У 158 больных инфекционным мононуклеозом изучены в динамике показатели активности перекисного окисления липидов и антиоксидантной системы в зависимости от тяжести клинического течения заболевания.

Доказано, что у больных инфекционным мононуклеозом по мере нарастания тяжести заболевания достоверно активируется перекисное окисление липидов, в связи с чем повышаются окислительная активность плазмы крови, концентрация в крови диеновых коньюгатов и малонового диальдегида, происходит ослабление активности антиоксидантной системы, что ассоциировано со снижением активности антиокислительных ферментов эритроцитов (каталазы, супероксиддисмутазы, глутатионпероксидазы, глутатионредуктазы), активности глутатионпероксидазы и глутатионредуктазы в плазме крови и понижением концентрации общего и восстановленного глутатиона в крови, а также снижением антиокислительной активности плазмы крови и эритроцитов.

КЛЮЧЕВЫЕ СЛОВА: инфекционный мононуклеоз, перекиси липидов, антиоксидантная система, каталаза, супероксиддисмутаза, глутатионтероксидаза, глутатионредуктаза, диеновые коньюгаты, малоновый диальдегид, глутатион

\section{INTRODUCTION}

Infectious mononucleosis (IM) is a widespread disease of childhood, which has been increasingly diagnosed among adults recently. The etiological factor of myocardial infarction is Epstein-Barr virus (EBV) in most cases, which is characterized by a discrete symptom complex followed by damage of the immune system, namely, the lifetime persistence of the virus in B lymphocytes. EBV is a lymphotropic agent that causes the development of lymphoproliferative syndromes and immune deficiency [1-3].

Other clinical manifestations are possible in addition to the triad of symptoms lymphadenopathy, tonsillitis, hepatosplenomegaly in case of IM, that are associated with heart damage (myocardium, pericardium, coronary arteries), central and peripheral nervous system (meningitis, meningoencephalitis), kidney (nephritis), pancreatitis orchites and others [4-6].

Previous studies have shown that activation of lipid peroxidation, which is accompanied by the formation of primary and secondary lipid hydroperoxides with toxic properties, plays an important role in the pathogenesis of cell destruction of various organs [7-9]. However, the processes of free-radical lipid oxidation and antioxidant protection have been poorly understood in patients with IM, and the data obtained are contradictory.

\section{OBJECTIVE}

The aim of the work was to study the state of lipid peroxidation and antioxidant system of the disease in patients with various forms of severity of IM in the dynamics.

\section{MATERIALS AND METHODS}

158 patients with IM (80 women and 78 men) aged from 18 to 32 years were examined. IM was mild in 58 patients, in moderately severe form in 56 patients and 44 patients had severe form. The work was performed at the Department of General and Clinical Immunology and Allergology, Medical Faculty, V. N. Karazin Kharkiv National University on the basis of the Regional Clinical Infectious Diseases Hospital in Kharkiv within the framework of the research theme of the department «Study of the role of immune, autoimmune and metabolic disorders in the pathogenesis and consequences of the infectious process caused by herpes viruses», state registration № 0112U005911. The study is open, controlled, conducted in accordance with the Declaration of Helsinki and the principles of GCP and approved by LEC [10].

All patients underwent a complete clinical, haematological, biochemical and immunelogical examination.

The diagnosis of IM was established on the basis of the clinical picture of the disease, taking into account epidemiological analysis 
data and confirmed by detecting EBV DNA in serum and saliva of patients with EBV, also studied the serological markers of EBV that are immunoglobulin's (IgM, IgG) to capsid (VCA), to the nuclear (NA) and early (EA) antigens by means of enzyme linked immunosorbent assay (ELISA) using the IBL (Germany) and VectorBest (RF) kits, detection of EBV DNA by blood polymerase chain reaction (PCR).

A comprehensive study of patients included the study of peripheral blood with the detection of atypical mononuclear cells, the activity of alanine, aspartic transaminases, the content of bilirubin fractions in the blood. The state of lipid peroxidation (LPO) in patients with IM was appreciated according to the content of dyne conjugates (DC), malondialdehyde (MDA), the serum total oxidative activity (TOA). The state of the antioxidant system was assessed according to the determination of the serum and erythrocytes total antioxidant activity (TAA), the activity of catalase, superoxide dismutase, glutathione peroxidase, glutathione reductase of erythrocytes, total glutathione, oxidized and reduced serum glutathione. Examination of patients was carried out in the first days upon admission to the clinic, then on the 5th, 10th, 20th and 30th days of treatment. The control group consisted of 30 healthy people aged from 18 to 30 years, in whom the indicators of oxidative and antioxidant activity of blood plasma and erythrocytes were determined.

All patients received standard therapy that included anti-viral medications; valaciclovir $1000 \mathrm{mg} 3$ times daily, detoxification therapy (reosorbilact, $5 \%$ glucose solution), hepatoprotectors, antipyretic drugs, antihistamines.

Statistical processing of the research results was carried out using the Statistika 6.0 for Windows (Stat Soft Inc., USA) on a personal computer with a Pentium II Celeron 850 PPGA processor. These results are presented in an article with assessing the reliability of differences by the Student's criterion at $\mathrm{p}<0.05$. The non-parametric Spearman method of correlation analysis was used to balance the relationship between various biochemical parameters.

\section{RESULTS}

The clinical picture of IM was typical in most patients. Patients complained of general weakness, headache, myalgia, arthralgia, sore throat when swallowing, sweating, and fever up to $38-39.6^{\circ} \mathrm{C}$, which persisted for 15 to 30 days and often longer during the early days of the disease. Typical changes specific for IM were detected in the clinical analysis of blood, leukopenia was detected more often at the beginning of the disease, which was later replaced by leucocytosis $\left(9-10 \times 10^{9} / 1\right)$, the content of mononuclear lymphocytes and monocytes significantly increased, reaching 50 $80 \%$ of the total number of leukocytes. The detection of atypical mononuclear was a characteristic sign of IM in the blood (20\% or more). The duration of preservation of wide plasma lymphocytes averaged around 2-3 weeks, sometimes up to 2 months, the ESR remained within the normal range or slightly increased in this category of patients.

An ultrasound examination revealed an enlarged liver, spleen, peribronchial and peritracheal lymph nodes.

Anterior and posterior cervical, submandibular and axillary lymph nodes were enlarged in all patients with IM.

Cytolytic syndrome was diagnosed in 43 $(76.3 \%)$ patients with moderate-severe course of IM and in $30(88.7 \%)$ patients with severe course, which proceeded with an increase of direct bilirubin in blood. The level of direct bilirubin increased at an average of $15.0 \pm$ $0.9 \mu \mathrm{mol} / \mathrm{l}(\mathrm{p}<0.01)$, the ALT activity $-1.85 \pm$ $0.09 \mathrm{mmol} / \mathrm{l}, \quad$ ACT $-1.12 \pm 0.07 \mathrm{mmol} / \mathrm{l}$ $(\mathrm{p}<0.01)$ in patients with a moderate-severe course of IM. In patients with severe course of IM, the level of direct bilirubin in the blood increased on average to $23.9 \pm 1.1 \mu \mathrm{mol} / \mathrm{l}$ ( $\mathrm{p}<0.01)$, ALT activity - to $2.24 \pm 0,1 \mathrm{mmol} / \mathrm{l}$ $(\mathrm{p}<0.01), \quad$ ACT activity - to $1.35 \pm$ $0.08 \mathrm{mmol} / 1 \quad(\mathrm{p}<0.01)$, which indicated liver involvement in the pathological process.

The content of direct bilirubin, the activity of ALT and ACT in blood in patients with IM with a mild course did not significantly differ from those in the control group.

Direct bilirubin content, ALT and ACT activity in blood normalized closer to the 20th day in the course of treatment in patients with moderate-severe IM, whereas in case of severe course - to the 30th day, and often later.

The results of the study of indicators of the oxidative and antioxidant systems in patients with IM are presented in table, from which it follows that TOA of blood plasma $(p<0.01)$, concentration in blood primary (DC) and secondary (MDA) lipid hydroperoxides $(p<0.01)$ increase significantly in accordance 
with the severity of the disease in patients with IM. A high direct correlation was found ( $r=0.65 ; r=0.69$ ) between the blood levels of DC and MDA, on the one hand, and the overall oxidative activity of blood plasma, on the other hand, which indicates the important role of lipid hydroperoxides in increasing the oxidative activity of blood plasma in these patients with IM.

The activation of lipid peroxidation in patients with IM of a mild course was accompanied by a statistically significant decrease in the TAA of blood plasma and erythrocytes $(p<0.001)$, a decrease in the activity of erythrocyte antioxidant enzymes catalase $(p<0.001)$, superoxide dismutase $(\mathrm{p}<0.001)$, glutathione peroxidase $(\mathrm{p}<0,01)$, an increase in activity of plasma glutathione reductase $(p<0.001)$, reduced glutathione $(\mathrm{p}<0.001)$, which indicates an increase in the activity of the glutathione system, which is involved in the inactivation of lipid hydroperoxides in the blood and tissues [11-13].

As the clinical, immunological and haematological parameters improved while treating patients with IM with a mild course, the indicators of the LPO decreased and the activity levels of the antioxidant system increased, and by the 20th day of treatment the concentration of $\mathrm{DC}$ in the blood decreased to $1.4 \pm 0$, MDA on average $03 \mu \mathrm{mol} / \mathrm{l}(\mathrm{p}<0.001)$, MDA on average up to $0.40 \pm 0.03 \mu \mathrm{mol} / 1(\mathrm{p}<0.001)$ and TOA of blood plasma on average to $3.75 \pm$ $0.4 \% \quad(\mathrm{p}<0.001)$. The plasma antioxidant activity was statistically significantly increased by an average of $6.6 \pm 0.8 \%$ and of erythrocytes by an average of $39.6 \pm 1.6 \%$ ( $1<0.001)$, the activity of catalase increased on average to $66.4 \pm 2,0 \mathrm{mmol} / \mathrm{s} . \mathrm{mg}$ protein $(\mathrm{p}<0.001)$ in erythrocytes, erythrocyte superoxide dismutase, on average, up to $62.2 \pm 2.1 \mathrm{units} / \mathrm{mg}$ ( $\mathrm{p}$ $<0.001$ ), glutathione peroxidase, on average, up to $180.5 \pm 9.0 \mu \mathrm{mol} / \mathrm{s} . \mathrm{mg}$ protein (p $<0.001$ ), blood plasma glutathione peroxidase, on average, up to $4.9 \pm 0.13 \mathrm{mkkat} / \mathrm{l}(\mathrm{p}<0.05)$, plasma glugate reductase, on average, up to 2.1 $\pm 0.03 \mathrm{mkkat} / \mathrm{l} \quad(\mathrm{p}<0.05)$, erythrocyte glutathione reductase, on average, up to $76.5 \pm$ $2.5 \mu \mathrm{mol} / \mathrm{s} . \mathrm{mg}$ protein $(\mathrm{p}<0,05)$, the concentration of total glutathione in blood did not significantly change $(\mathrm{p}>0.05)$, the content of oxidized glutathione in blood decreased, on average, to $55.6 \pm 6.4 \mathrm{mmol} / \mathrm{l}(\mathrm{p}<0.05)$, and the level of reduced glutathione increased, on average, to $974.8 \pm 7.3 \mu \mathrm{mol} / 1(\mathrm{p}>0.05)$ and did not significantly differ from the corresponding indicators of the control group.

Analysis of the obtained data (tab. 1) showed that severity of the disease increases in parallel with the increase of the activity of lipid peroxidation and the decrease in the activity of the antioxidant system in patients with IM, that manifests in an increase in the TOA of blood plasma $(p<0.001)$, the concentration of DC $(\mathrm{p}<0.001)$ and MDA $(\mathrm{p}<0.001)$, and in a decrease of the TAA of plasma $(p<0.001)$ and erythrocytes $(\mathrm{p}<0.001)$, the actioxidative activity of erythrocyte enzymes - catalase $(\mathrm{p}<0.001)$, superoxide dismutase $(\mathrm{p}<0.001)$, glutathione peroxidase $(\mathrm{p}<0.001)$, glutathione reductase $(\mathrm{p}<0.001)$; plasma glutathione peroxidase and plasma glutathione reductase $(\mathrm{p}$ $<0.01)$, the concentration of total and reduced glutathione in blood $(\mathrm{p}<0.001)$ and the content of oxidized glutathione in blood ( $\mathrm{p}<0.001$ ), which indicates a pronounced imbalance between the processes of radical oxidation of lipids and antioxidant protection.

Table

Indicators of lipid peroxidation and antioxidant systems in patients with IM $(\mathrm{M} \pm \mathbf{m})$

\begin{tabular}{|l|c|c|c|c|}
\hline \multicolumn{1}{|c|}{ Indicator } & $\begin{array}{c}\text { Control } \\
(\mathbf{n = 3 0})\end{array}$ & $\begin{array}{c}\text { Mild IM } \\
(\mathbf{n}=\mathbf{5 8})\end{array}$ & $\begin{array}{c}\text { Moderate- } \\
\text { severe IM } \\
(\mathbf{n = 5 6})\end{array}$ & $\begin{array}{c}\text { Severe IM } \\
(\mathbf{n = 4 4})\end{array}$ \\
\hline $\begin{array}{l}\text { Total oxidative activity of } \\
\text { plasma, \% }\end{array}$ & $4,3 \pm 0,3$ & $\begin{array}{c}6,7 \pm 0,45 ; \\
\mathrm{p}<0,001\end{array}$ & $\begin{array}{c}9,3 \pm 0,52 ; \\
\mathrm{p}<0,001\end{array}$ & $\begin{array}{c}12,7 \pm 0,75 ; \\
\mathrm{p}<0,001\end{array}$ \\
\hline Dyne conjugates, $\mathrm{\mu mol} / \mathrm{l}$ & $1,2 \pm 0,02$ & $\begin{array}{c}2,4 \pm 0,03 ; \\
\mathrm{p}<0,001\end{array}$ & $\begin{array}{c}3,7 \pm 0,06 ; \\
\mathrm{p}<0,001\end{array}$ & $\begin{array}{c}5,1 \pm 0,07 ; \\
\mathrm{p}<0,001\end{array}$ \\
\hline Malonic dialdehyde, moll/1 & $0,35 \pm 0,015$ & $\begin{array}{c}0,8 \pm 0,03 ; \\
\mathrm{p}<0,001\end{array}$ & $\begin{array}{c}2,2 \pm 0,04 ; \\
\mathrm{p}<0,001\end{array}$ & $\begin{array}{c}2,8 \pm 0,04 ; \\
\mathrm{p}<0,001\end{array}$ \\
\hline $\begin{array}{l}\text { Total antioxidant activity of } \\
\text { plasma, \% }\end{array}$ & $8,2 \pm 0,4$ & $\begin{array}{c}6,3 \pm 0,08 ; \\
\mathrm{p}<0,001\end{array}$ & $\begin{array}{c}5,4 \pm 0,65 ; \\
\mathrm{p}<0,001\end{array}$ & $\begin{array}{c}3,6 \pm 0,05 ; \\
\mathrm{p}<0,001\end{array}$ \\
\hline $\begin{array}{l}\text { Total antioxidant activity of red } \\
\text { blood cells, \% }\end{array}$ & $41,5 \pm 1,2$ & $\begin{array}{c}34,2 \pm 0,9 ; \\
\mathrm{p}<0,001\end{array}$ & $\begin{array}{c}22,7 \pm 1,0 ; \\
\mathrm{p}<0,001\end{array}$ & $\begin{array}{c}11,4 \pm 0,8 ; \\
\mathrm{p}<0,001\end{array}$ \\
\hline
\end{tabular}


Continuation of the table

\begin{tabular}{|c|c|c|c|c|}
\hline $\begin{array}{l}\text { Erythrocyte catalase activity, } \\
\text { mmoll/sg protein }\end{array}$ & $67,2 \pm 2,6$ & $\begin{array}{l}50,4 \pm 1,7 \\
p<0,001\end{array}$ & $\begin{array}{l}42,6 \pm 1,2 \\
p<0,001\end{array}$ & $\begin{array}{c}30,4 \pm 1,1 \\
\mathrm{p}<0,001\end{array}$ \\
\hline $\begin{array}{lr}\text { Erythrocyte } & \text { superoxide } \\
\text { dismutase activity, units/mg Hb }\end{array}$ & $63,8 \pm 2,3$ & $\begin{array}{l}53,4 \pm 1,8 \\
p<0,001\end{array}$ & $\begin{array}{c}43,7 \pm 1,8 \\
\mathrm{p}<0,001\end{array}$ & $\begin{array}{c}36,2 \pm 1,5 \\
p<0,001\end{array}$ \\
\hline Total blood glutathione, $\mathrm{mmol} / \mathrm{l}$ & $1076 \pm 8,2$ & $\begin{array}{c}990,0 \pm 9,4 \\
p<0,05\end{array}$ & $\begin{array}{l}735,6 \pm 8,6 \\
\mathrm{p}<0,001\end{array}$ & $\begin{array}{c}564,7 \pm 6,4 \\
p<0,001\end{array}$ \\
\hline $\begin{array}{l}\text { Oxidized blood glutathione, } \\
\mathrm{mmol} / \mathrm{l}\end{array}$ & $50,4 \pm 4,7$ & $\begin{array}{l}86,5 \pm 5,2 \\
p<0,001\end{array}$ & $\begin{array}{l}215,6 \pm 4,6 \\
\mathrm{p}<0,001\end{array}$ & $\begin{array}{c}254,5 \pm 3,9 \\
\mathrm{p}<0,001\end{array}$ \\
\hline $\begin{array}{l}\text { Reduced blood glutathione, } \\
\text { mmol/l }\end{array}$ & $940,5 \pm 8,3$ & $\begin{array}{l}990,0 \pm 8,2 \\
\mathrm{p}<0,001\end{array}$ & $\begin{array}{l}524,7 \pm 6,0 \\
\mathrm{p}<0,001\end{array}$ & $\begin{array}{c}326,3 \pm 3,6 \\
p<0,001\end{array}$ \\
\hline $\begin{array}{l}\text { Erythrocyte } \begin{array}{l}\text { glutathione } \\
\text { peroxidase activity, } \mu \mathrm{mol} / \mathrm{sg} \\
\text { protein }\end{array} \\
\end{array}$ & $183,8 \pm 5,6$ & $\begin{array}{c}159,4 \pm 6,1 \\
p>0,05\end{array}$ & $\begin{array}{c}91,6 \pm 5,2 \\
p<0,001\end{array}$ & $\begin{array}{c}62,7 \pm 4,5 \\
p<0,001\end{array}$ \\
\hline $\begin{array}{l}\text { Plasma glutathione peroxidase } \\
\text { activity, mkkat/l }\end{array}$ & $3,9 \pm 0,15$ & $\begin{array}{c}3,1 \pm 0,13 \\
p<0,01\end{array}$ & $\begin{array}{c}1,85 \pm 0,02 \\
\mathrm{p}<0,001\end{array}$ & $\begin{array}{c}0,9 \pm 0,02 \\
\mathrm{p}<0,001\end{array}$ \\
\hline $\begin{array}{l}\text { Glutathione reductase plasma } \\
\text { activity, mkkat/l }\end{array}$ & $2,0 \pm 0,02$ & $\begin{array}{l}2,9 \pm 0,03 \\
p<0,001\end{array}$ & $\begin{array}{l}1,6 \pm 0,01 \\
p<0,001\end{array}$ & $\begin{array}{l}0,9 \pm 0,01 \\
\mathrm{p}<0,001\end{array}$ \\
\hline $\begin{array}{l}\text { Erythrocyte } \begin{array}{l}\text { glutathione } \\
\text { reductase activity, } \mu \mathrm{mol} / \mathrm{sg} \\
\text { protein }\end{array} \\
\end{array}$ & $73,7 \pm 2,6$ & $\begin{array}{l}96,5 \pm 2,0 \\
p<0,001\end{array}$ & $\begin{array}{c}62,7 \pm 1,9 \\
p<0,001\end{array}$ & $\begin{array}{c}53,7 \pm 1,9 \\
\mathrm{p}<0,001\end{array}$ \\
\hline
\end{tabular}

Note: Reliability of differences $p$ compared with the control group.

The activity of lipid peroxidation decreases and the activity of the anti-peroxide system increases while conducting antiviral therapy in patients with moderate-severe and severe course of IM, however, the full normalization of the activity indicators of these systems was not observed by the 30th day of the disease, which is consistent with the data of other authors [14], and indicates a severe violation of antioxidant protection in patients with severe and moderate-severe forms of IM, which may be associated with adverse outcomes of IM.

\section{DISCUSSION}

Lipid peroxidation is one of the most important biological processes that constantly occurs in the human body and is actively involved in the processes of adaptation, antiinfective protection, removal of endo- and exotoxins, tumour cells and destroyed tissues, regulation of vascular tone, permeability of cell membranes and the vascular wall, haemostasis, etc. $[13,15-16]$. Under normal conditions, LPO flows continuously inside all cells at an extremely low level, providing regulation of the structure and function of cell membranes [15]. The most reactive in this regard cells are of the monocyte-macrophage system of the blood, Kupffer cells of the liver, alveolar macrophages, macrophages of connective tissue, Langerhans cells, osteoclasts, glial astrocytes, which activated when exposed to infection, antibodies, aggregated Ig, leptins, Creactive protein, complement components [17].

EBV in patients with IM leaves an enveloped antigen on the cell membrane, modifying it by penetrating B lymphocytes, which leads to activation of NK cells and cytotoxic T lymphocytes [18-20], and destruction of infected cells. As a result of cytolysis, cell degradation products enter the bloodstream, which are phagocyted by the means of neutrophilic granulocytes and macrophages.

Granulocyte lysosomes contain the enzyme NAD, NAD-P-oxidase, which is activated during phagocytosis and catalyses the recovery process of molecular oxygen with the formation of oxygen with an unpaired electron $\left(\mathrm{O}^{-}\right)$. The intracellular superoxide dismutase (SOD) enzyme binds this oxygen with hydrogen producing hydrogen peroxide $\left(\mathrm{H}_{2} \mathrm{O}_{2}\right)$, which is then cleaved by catalase and glutathione peroxidase with the formation of hydroxide $\left(\mathrm{HO}^{-}\right)$and hydroperoxide $\left(\mathrm{HO}_{2}^{-}\right)$radicals, which inactivate glutathione. At the same time, glutathione is converted to the oxidized form, and under the influence of the glutathione reductase, it turns into reduced glutathione and provides binding of lipid hydroxides [21-23]. Glutathione peroxidase and glutathione transferase are able to restore the hydroperoxy groups of oxidized phospholipids directly in the cell membranes without prior hydrolysis by phospholipase or free fatty acids. 
Consequently, glutathione and enzymes of its metabolism are one of the most important universal defence mechanisms and the central link of the homeostatic system of the body, they play a primary role in the formation of the body's resistance to aggressive factors [24-25].

Glutathione is formed in the liver and contains glutamic acid, cysteine and glycine. Glutathione including functional group of $\mathrm{SH}$ participates in oxidation-reduction reactions, being a donor of hydrogen, passing from reduced to the oxidized form.

The antioxidant enzymes (catalase, superoxide dismutase, glutathione peroxidase, glutathione reductase, glutathione) maintain free radical oxidation at a safe level under the normal conditions, they restore syngeneic oxygen creating less active forms, and also suppress the formation of $\mathrm{HO}^{-}, \mathrm{HO}_{2}^{-}, \mathrm{H}_{2} \mathrm{O}_{2}$ and destroy lipid hydroxides formed in excess amount [26].

The LPO system is well balanced and functions on the basis of feedback, since LPO products inhibit the activity of antioxidant enzymes. However, activation of LPO is accompanied by increased activity of glutathione reductase and the concentration of reduced glutathione in the blood in patients with mild IM, which connects the primary and secondary hydroxide lipids, thereby significantly accelerating the process of the activity antioxidant enzymes recovery (catalase, superoxide dismutase, glutathione peroxidase), blood plasma antioxidant activity and red blood cells.

The activation of the LPO leads to a deep suppression of the antiperoxide system activity, and its normalization proceeds at a slower rate over a long period in patients with IM of severe and moderate-severe course.

We found a decrease in the activity of catalase, superoxide dismutase, glutathione peroxidase, glutathione reductase in plasma and erythrocytes, the concentration of total and reduced glutathione in the blood of IM patients with severe and moderate-severe course, that indicates a deep disruption of the functioning of various parts of the antioxidant system and contributes to the increased formation of active forms of oxygen, hydroxide and hydroperoxide radicals, hydrogen peroxide in cells of the antioxidant system causing oxidation of unsaturated fatty acids of cell membrane and the formation of primary and secondary lipid hydroperoxides, which have a toxic effect not only on EBV, but also on other cellular structures.

Lipid peroxides are highly reactive and can suppress the activity of catalase, superoxide dismutase, glutathione peroxidase and glutathione reductase, cause the degradation of SH-containing compounds, depolymerisation of DNA, induce vasospasm, increase the permeability of cell membranes, endothelium damage, enhance platelet aggregation [27].

Oxidized glutathione accumulates in the tissues of patients with severe and moderatesevere IM as a result of a decrease in the activity of glutathione reductase, and also has toxic properties. Oxidized glutathione inactivates membrane ATPase, hexokinase, glucose-6-dehydrogenase, inhibits phosphorylation and nuclear synthesis of RNA, inhibits protein synthesis due to the formation of protein-thiol-glutathione crosslinks [28].

If the systems of generation and inactivation of free radicals are not balanced, the ordered structure of the monooxygenase complex can be destroyed, and its components can attack the polyunsaturated fatty acids of the surrounding membranes in the absence of a normal substrate.

In this case, the formation of toxic lipid peroxides is possible, and subsequently secondary products of LPO, which disrupt the functional state of the liver that plays an important role in the processes of detoxification in various pathological conditions. Glutathione, glutathione peroxidase, glutathione reductase and cytochrome P-450 are formed in hepatocytes and involved in inactivating of primary and secondary lipid hydroperoxides. As a result of the toxic effect of active forms of oxygen and lipid hydroperoxides in the liver, blood circulation is disturbed and hypoxia of hepatocytes develops, lipid peroxidation is activated in cell membranes and the activity of antioxidant enzymes and cytochrome P-450 is reduced. These processes result in hepatocytes destruction, which is accompanied by an increase in direct bilirubin, the activity of ACT and ALT in blood. A high direct correlation was found between the indicators of plasma TOA, direct bilirubin concentration, ALT and ACT activity in the blood $(r=0.62 ; r=0.64$; $r=0.62$ ), which indicates the important role of the LPO products in the development of cytolytic syndrome in patients with severe and moderate-severe course of IM. 
Our study showed that, the process of lipid peroxidation increases and the activity of the antioxidant system decreases in parallel with the severity of the disease in patients during the acute period of the IM. Deficiency of antioxidant enzymes (catalase, superoxide dismutase, glutathione peroxidase, glutathione reductase), reduction of their activity and concentration of total glutathione in the blood of patients with IM lead to the breakdown of protective mechanisms and, as a result, to increased LPO-free radical chain process, which uncontrolled growth causes irreversible damage to the membranes of various cells underlying visceropathy in patients with IM.

Consequently, the level of adaptive capacity of antioxidant enzymes decreases in patients with IM. It may be a result of primary or secondary enzymopathies due to the toxic effect of reactive forms of oxygen and lipid hydroperoxides on enzymes. Our findings confirm the expediency of using antioxidants in the treatment of patients with IM.

\section{CONCLUSIONS}

1. Lipid peroxidation significantly increase and the activity of the antioxidant system decrease in patients with infectious mononucleosis in the acute period of the disease, as evidenced by the increased concentration of dyne conjugates, malonic dialdehyde and total oxidative plasma activity in the blood, reduced activity of the total antioxidant activity of plasma and erythrocytes, the decrease in the activity of antioxidant enzymes of erythrocytes catalase, superoxide dismutase, glutathione peroxidase, glutathione peroxidase and glutathione reductase of blood plasma, the decrease in the concentration of glutathione in the blood.

2. The most pronounced disorders of lipid peroxidation and antioxidant system activity were found in patients with moderate-severe and severe infectious mononucleosis.

3. The development of cytolytic syndrome in infectious mononucleosis is associated with the action of reactive oxygen forms species and lipid hydroperoxide.

\section{PROSPECTS FOR FUTURE RESEARCHES}

It seems to be appropriate to study further clinical course of IM after using various antioxidants in addition to existing therapy to test the ability to suppress viral replication and to define the most effective compound.

\section{REFERENCES}

1. Picard C. et al. Primary immunodeficiency diseases: an update on the classification from the International Union of Immunological Societies Expert Committee for Primary Immunodeficiency 2015 // Journal of clinical immunology. - 2015. - T. 35. - No. 8. - p. 696-726.

2. Picard C. et al. International union of immunological societies: 2017 primary immunodeficiency diseases committee report on inborn errors of immunity // Journal of clinical immunology. - 2018. - T. 38. - No. 1. - p. 96-128.

3. Kucuk Z. Y. et al. CTP synthase 1 deficiency in successfully transplanted siblings with combined immune deficiency and chronic active EBV infection // Journal of clinical immunology. - 2016. - T. 36. - No. 8. p. $750-753$.

4. Kim H. J. et al. Systemic multi-organ involvement in chronic active Epstein-Barr virus disease // Pediatrics International. - 2015. - T. 57. - No. 4. - p. 802-804.

5. Amer A. et al. Epstein Barr virus infection was associated with nephrotic syndrome, severe thrombocytopenia and coombs positive haemolytic anaemia // Acta Paediatrica. - 2018.

6. Shah S., Schroeder S. A rare case of primary EBV infection causing acute acalculous cholecystitis // Journal of Pediatric Surgery Case Reports. - 2015. - T. 3. - No. 7. - p. 285-288.

7. Asmat U., Abad K., Ismail K. Diabetes mellitus and oxidative stress-a concise review // Saudi Pharmaceutical Journal. - 2016. - T. 24. - No. 5. - p. 547-553.

8. Bhattacharyya A. et al. Oxidative stress: an essential factor in the pathogenesis of gastrointestinal mucosal diseases // Physiological reviews. - 2014. - T. 94. - No. 2. - p. 329-354.

9. Yin G. et al. Lipid peroxidation-mediated inflammation promotes cell apoptosis through activation of NF$\kappa \mathrm{B}$ pathway in rheumatoid arthritis synovial cells // Mediators of inflammation. - 2015. - T. 2015.

10. World Medical Association et al. WMA Declaration of Helsinki-ethical principles for medical research involving human subjects. 2013 // Google Scholar. - 2015.

11. Robaczewska J. et al. Role of glutathione metabolism and glutathione-related antioxidant defense systems in hypertension // J Physiol Pharmacol. - 2016. - T. 67. - No. 3. - p. 331-337. 
12. Yang W. S., Stockwell B. R. Ferroptosis: death by lipid peroxidation // Trends in cell biology. - 2016. T. 26. - No. 3. - p. 165-176.

13. Gaschler M. M., Stockwell B. R. Lipid peroxidation in cell death // Biochemical and biophysical research communications. - 2017. - T. 482. - No. 3. - p. 419-425.

14. Chaban T. V., Zhuravskaja N. A. Sostojanie processov perekisnogo okislenija lipidov i antioksidantnoj sistemy i trombocitarnogo zvena gomeostaza u bol'nyh infekcionnym mononukleozom // Klin.med. 2014. No. 2. - p. 52-55.

15. Kagan V. E. Lipid Peroxidation In Biomembranes: 0. - CRC press, 2018.

16. Ayala A., Muñoz M. F., Argüelles S. Lipid peroxidation: production, metabolism, and signaling mechanisms of malondialdehyde and 4-hydroxy-2-nonenal // Oxidative medicine and cellular longevity. 2014. - T. 2014.

17. Verma N., Saraf S. A role of macrophages. An overview // Journal of Drug Delivery and Therapeutics. 2017. - T. 7. - No. 6. - p. 91-103.

18. Djaoud Z. et al. Two alternate strategies for innate immunity to Epstein-Barr virus: One using NK cells and the other NK cells and $\gamma \delta \mathrm{T}$ cells // Journal of Experimental Medicine. $-2017 .-$ T. 214. - No. 6. p. $1827-1841$.

19. Takada $\mathrm{H}$. et al. EBV induces persistent NF- $\mathrm{B}$ activation and contributes to survival of EBV-positive neoplastic T-or NK-cells // PloS one. - 2017. - T. 12. - No. 3. - p. e0174136.

20. Takada H. et al. Correction: EBV induces persistent NF- $\kappa B$ activation and contributes to survival of EBVpositive neoplastic T-or NK-cells // PloS one. - 2017. - T. 12. - No. 8. - p. e0182682.

21. Nimse S. B., Pal D. Free radicals, natural antioxidants, and their reaction mechanisms // Rsc Advances. 2015. - T. 5. - No. 35. - p. 27986-28006.

22. Liu Y. et al. Emerging regulatory paradigms in glutathione metabolism // Advances in cancer research. Academic Press, 2014. - T. 122. - p. 69-101.

23. Stockwell B. R. et al. Ferroptosis: a regulated cell death nexus linking metabolism, redox biology, and disease // Cell. - 2017. - T. 171. - No. 2. - p. 273-285.

24. Hayyan M., Hashim M. A., AlNashef I. M. Superoxide ion: generation and chemical implications // Chemical reviews. - 2016. - T. 116. - No. 5. - p. 3029-3085.

25. Pisoschi A. M., Pop A. The role of antioxidants in the chemistry of oxidative stress: A review // European journal of medicinal chemistry. - 2015. - T. 97. - p. 55-74.

26. Ighodaro O. M., Akinloye O. A. First line defence antioxidants-superoxide dismutase (SOD), catalase (CAT) and glutathione peroxidase (GPX): Their fundamental role in the entire antioxidant defence grid // Alexandria Journal of Medicine. - 2017.

27. Nimse S. B., Pal D. Free radicals, natural antioxidants, and their reaction mechanisms // Rsc Advances. 2015. - T. 5. - No. 35. - p. 27986-28006.

28. $\mathrm{Hu} \mathrm{J}$. et al. The role of oxidative stress in EBV lytic reactivation, radioresistance and the potential preventive and therapeutic implications // International journal of cancer. - 2017. - T. 141. - No. 9. p. $1722-1729$. 